\section{Is Emile in the Garden of Eden? Western ideologies of nature}

\section{Lynley Tulloch}

University of Waikato, New Zealand
Policy Futures in Education 2015, Vol. 13(I) 20-41

(C) Author(s) 2015

Reprints and permissions: sagepub.co.uk/journalsPermissions.nav DOI: 10.1 I77/|4782103|4566729 pfe.sagepub.com

(S)SAGE

\begin{abstract}
This paper will explore ideologies of nature including the 'Garden of Eden' and 'wildernesses'. It locates these ideologies as morphing to accommodate the later trajectory of the Enlightenment Project and its endorsement of modern Western scientific and technological principles. Beginning with the premise that nature is unknowable, this paper offers a critique of dominant Western cultural ideologies that function to domesticate and order nature. This goes hand in hand with ideologies and practices of domination and control in the name of scientific, technological and capitalist neo-liberal economic 'development'. The assumption that the boundary between nature and humans is crossable through scientific and technological knowledge is one that can be explored and challenged by examining how such knowledge is from the outset ideologically constructed. This paper will look at the concept of alienation from nature (as expressed by Jean-Jacques Rousseau in 'Emile' and Karl Marx) to explore how modern schooling and the capitalist economy shape human-nature relations.
\end{abstract}

\title{
Keywords
}

nature, ideology, alienation, critical discourse analysis

\section{Introduction}

Jean-Jacques Rousseau (1712-1778) believed in the immortal soul. He wrote, "I sense my soul. I know it by sentiment and thought. Without knowing what its essence is, I know that it exists" (Rousseau, 1979: 283). Many of us consider nature in the same way. Sense experience, emotion and thought are critical ways that humans come to believe that they know nature. But can we know its essence?

This paper sets out to explore the many and tangled webs of thought on nature. Drawing on Marxist thought, it is argued that nature is an ideological construct linked to particular historical social and economic conditions. In the West, ideologies of nature have been strongly influenced by a number of strands of thought. Eighteenth and nineteenth century ideas of nature consist of a recognition of "Enlightenment and Romantic themes, with at best a nod in the direction of an hypostasized and unified 'Judeo-Christian' tradition"

Corresponding author:

Lynley Tulloch, Department of Policy, Cultural and Social Studies, University of Waikato, Waikato, New Zealand. Email: lynleyt@waikato.ac.nz 
(Alder, 2006: p. 5). Themes that begin to emerge from these explorations include: nature as a terrestrial paradise; divinely ordained human stewardship over nature; nature's death and plunder; nature as a primordial wilderness, nature as nurturing mother; and nature as brute matter, to name a few (Alder, 2006).

I have taken Jean-Jacques Rousseau's concept of nature as an interesting illustration of the complexity of ideas of nature. Rousseau has been dualistically situated in the camp of both the Romantics and Naturalists of the Eighteenth Century (Viroli, 1988). Indeed, Maurizio Viroli (1988) argues that Rousseau's thoughts were unique in eighteenth century philosophy. He writes that, "unlike those who consider human reason capable of finding an answer to the important questions concerning the nature of the universe, he draws attention to the limits of the human intellect" (p.17). While situated somewhat in Enlightenment thought and the belief in reason and the sensation as the basis to understanding nature, Rousseau also maintained an element of mystery and the unknown.

The mysterious and the unknown are important spaces to develop further thought on nature. They counter the dominance of rationalist and Enlightenment thought that seeks to know and dissect nature. It also signals the importance of philosophy and critical thought in challenging dominant ideologies (or systems of belief) that may offer us impoverished versions and experiences of nature.

Erich Fromm argues that the experience of human separation from nature fuels the passion to become whole again through union with nature. Human wholeness, says Fromm, was the state in the Garden of Eden. Dispelled, humans search for an existential reality that overcomes separateness from nature, otherwise they will become insane (Fromm, 2005). This, says Fromm, is the particular problem of their birth. The historical locatedness of humans as individuals in a particular time and place in a particular time and place, means they are subject to the alienating features of any particular social order and the ideologies that already exist.

\section{Ideology}

In this paper I use a Marxist concept of 'ideology'. Ideology itself is a contested term and one that is used in a very specific way by Marx. I will use the definition as outlined by Richard Miller (1991) in his discussion of Marx's use of ideology. According to Miller, ideologies as discussed by Marx refer to "socially significant systems of belief, presupposition, or sentiment that depends of false perception of reality, the currency of which is due to truth-distorting social forces" (Miller, 1991: 72).

Historicization is an important aspect of this. Ideologies understood as 'systems of ideas' not only have social origins for Marx, but they also represent certain social interests that are integral to a particular historical epoch. In the case of capitalist society, the class interests of the bourgeoisie are represented through ideological means. In particular, the propagation of the belief that the economic relations are in everyone's interest is a good example. These ideologies represent the hallmarks of the Enlightenment tradition including human progress, technological development and mastery over nature. Through these ideologies, the true exploitative relations between the bourgeoisie and proletariat in capitalist society are concealed (Miller, 1991). The demystification of exploitative social relations and corresponding destruction of the non-human world is an important critical educational imperative.

Karl Marx (1818-1883) argued that, "[t]he production of ideas, of conceptions, of consciousness, is at first directly interwoven with the material activity and the material 
intercourse of men" (Marx and Engels, 1965: 472). This material basis means that ideologies are an expression of the relations of production, rather than an independent and creative force (Marx and Engels, 1965). According to Marx, ideologies also conceal the true nature (essence) of things. He referred to this process as fetishism. Marx wrote, "[t]he sense perception of a fetishist differs from that of a Greek because his sensuous existence is different. The abstract hostility between sense and spirit is inevitable so long as the human's sense for nature, or the human meaning of nature, and consequently the natural sense of man, has not been produced through man's own labour" (Marx, cited in Bottomore, 1963: 175). Thus ideologies also orient humans to a way of 'being' in the world, and through this process humans can become alienated from others and from non-human nature (Parsons, 1977).

Ideology has an historical character; it can only be understood through reference to a specific mode of production. For Marx, social history is a result of contradictions in material forces and is not driven by ideas. The capitalist mode of production, according to Marx, would have developed regardless of "the lust for gold, the greed for social power and the desire to dominate" (Harvey, 1982: 21). The formation of the capitalist mode of production is the result of powerful material forces. The inherent contradictions in the preceding modes of production led to "the rise of the capitalist class and the formation of the proletariat." (Harvey, 1982: 27). Capitalists as a class share common interests. They are "the personification of capital" (Marx, 1894: 824). They internalize the desire to accumulate capital for its own sake (Harvey, 1982: 28). Most importantly, this drive is seen to exist independently of the capitalist's will (Harvey, 1982: 29).

It is clear that ideological domination is experienced by both the dominant class and the oppressed. It is a form of what Erich Fromm (1900-1980), whose work builds on that of Karl Marx, calls "spiritual and moral captivity" (Fromm, 2005). While humanity is in the grip of "ecological and economic catastrophe" it is at the same time bound by a form of rationality that justifies such destructive action (Fromm, 2005: 7). At the root of this conundrum is the economic imperative of capital that seeks constant accumulation, and the corresponding ideology that constructs human and non-human nature as divided entities.

Language and ideology are inextricably connected. Language is not a direct reflection of the world that we experience as humans. Patti Lather (1996) argues that there is a need for academics to contest how "language... assumes a mirroring relationship between the word and the world" (p. 527). Gramsci describes how acceptance of language at face value is limiting ("limit ideas") (Hill, 2007: 104).

An example of how language constrains thought is the academic scientific construction of non-human nature in terms of 'biological diversity' or 'environment'. To write about or analyze nature within academia, the wider political arena and the everyday world requires a level of conformity with "the normalized, routinized, commodified structures of takenfor-granted intelligibility" (Lather, 1996: 527). The perceptions, values and beliefs that accompany the language used condition those subject to them to view non-human nature in a particular way (Dryzek, 2005: 9).

\section{Ideologies of nature}

Ideologies of nature are not neatly packaged in pre-defined categories. Neither are they 'free floating', abstract ideas. Rather they are messy and divergent, the result of historical 
trajectories that intersect and cross (Biro, 2005). By way of understanding the complexity of ideas about nature it is necessary to attempt to unravel these historical genealogical influences. In doing so, it becomes apparent that ideologies are interconnected with other (often contradictory) ideologies and the very real material conditions of a particular time and place (Biro, 2005). This Marxist reading of ideologies of nature regards them as inextricably linked to the material conditions of human existence. It follows from this that ideas about nature are not a 'universal' or self-evident, but rather socially and historically conditioned.

An important question is why particular constructions of nature become dominant. The construction of nature as a set of various and often competing ideas and assumptions draws attention to its historical, economic and socio-political contexts. The historical contextualization of modern-day ideas of nature is an important exercise. It allows exploration into how this concept is attached to particular discourses and the meanings, as well as the values and relationships, these support. For example, the evocation of nature as a "vast, evolving, nested set of mutually supporting homeostatic systems", as in the ecological sciences, has particular meanings and political implications attached to it (Whiteside, 2002: 9).

Ideologies of nature are often used to legitimate particular political and economic trajectories. Take, for example, ideologies of a natural Eden that spring from JudeoChristian mythology. These ideologies hinge on notions of plenitude, benevolence and divine goodness, reflecting the theology of Thomas Aquinas (1225-74) (Kinsley, 1995; Worster, 1993). But this myth of benevolence has been critiqued as anthropocentric, supporting a worldview of nature as divinely created for human use (Kinsley, 1995). This paper argues that the biblical narrative that humans have a form of 'dominion' or stewardship over the Earth is articulated with ideologies of technological progress and environmental management that are central to the recent expansion of global capitalism.

The focus on 'mastery' or 'domination' is deeply entrenched in Western thought. James Glover argues that following the intellectual tradition of René Descartes and Francis Bacon, there remains a strong adherence to the belief in knowledge as based on rational thought, with humans as the observers and nature as the observed (Glover, 2000). The rational appropriation of nature through scientific experiments and conventions is coupled with increases in technology which allow humans to believe they can know that which is nonhuman.

As humans, just how deeply we hold particular ideologies of nature is critical to the way we relate to it. For example, Worster (1993) argues that eighteenth century ideologies of natural Eden are so deeply entrenched in modern-day American consciousness that they have formed part of the national identity. This version of the Garden of Eden takes the form of a tamed wilderness and is revealed in farmland, pastures and parks (Thompson, 1983: 85). This ideology reflects a pastoral view of rural life as 'natural' and an adulation of the peacefulness of the countryside. Alternatively, ideological representations of non-human nature as "brute matter" (Dryzek, 2005: 57), or "an intractable domain of utility and danger" (Argyrou, 2005: 1) sit uncomfortably alongside those of a tranquil countryside. The notion of dominion over the natural world may blind humans to the horrors and oppression of domesticated farm animals.

Further, many environmentalists take a deep ecology view of the Earth based on the work of Arne Naess, and would argue against the above anthropocentric view of a benevolent 
nature and would see farm life as anything but natural (Whiteside, 2002). Thus, the idea of non-human nature and the related concept of 'wilderness' are social constructions and 'debating centers' (Whiteside, 2002). These ideas are drawn on in the political arena, in education, across cultures, in everyday life and in historical and philosophical contexts.

However, despite the 'taken-for-grantedness' of these concepts (or even perhaps because of their assumed 'naturalness'), they are always ideologically constituted. It is precisely this lack of critical investigation that makes these ideas so powerful, so deeply etched in human emotion and existence, and connected with spirituality and physical well-being.

The assumption that humans can 'know' non-human nature through scientific exploration and reason is historically specific to the Enlightenment period. This has coincided with an unprecedented loss of biological diversity and an increasing number of environmental issues. The truth claims of natural science have effectively established a physical 'natural reality', which has a powerful grip on the minds and hearts of those in the West. Henri Giroux (2001) proposes that science as a form of rationality is integral to Enlightenment thought, and he takes this idea further to link the knowledge it produces with broader hegemonic power relations.

Ideologies of nature are underscored by a particular ontological position of 'being' in the world (Fromm, 2007). In particular, it is argued that the positivist assumption that nature is "out there" and we can have "some kind of truthful access to it" is representative of an ideology that natural entities "have a singular being or is-ness potentially open to cognitive appropriation" (Castree, 1995: 34). Ontological challenges to Enlightenment thought that desacralizes nature and constructs nature and humanity as separate categories are important avenues for critique. Two distinct lines of thought that focus on a metaphysics of nature and humans are Marxist and radical ecological thought (including eco-feminist), which will be explored in this paper.

This opens up the quandary between materialist and idealist forces - in this case between a realist position (the belief in an ontologically material and real nature) and an epistemologically relativist position (nature is a relativist construct) (Castree, 1995; Cronon, 1990). It is taken as a given in this paper that the natural world does exist, but that we can never entirely 'know' it. Instead we can approach the question of nature by studying how nature and economies, as very real material processes, interact in a dialectical fashion with ideas about nature (Cronon, 1990).

Furthermore, the boundaries created between nature and humans through these ideological mechanisms serve to illustrate the concept of alienation. Alienation of humans from nature has been a central concern from the beginnings of Western philosophy. The analysis of this problem has traversed both modernist and post-modernist thought and often entails diverse political trajectories (Zimmerman, 1994). For the purposes of this paper I intend to highlight the concept of alienation from nature according to Jean-Jacques Rousseau (1712-1778) and Karl Marx (1818-1883).

\section{Historical intimacy: Ecology, economics and nature}

Donald Worster (1993) eloquently depicts the importance of land and the earth in human history. He writes, "until very recently, almost all people lived as intimately with other species and with the wind and weather as they did with their own kind. To ignore that long intimacy was to distort history" (p.vii). Marx, however, did not omit to consider the 
intimacy between humans and the land. Marx held a deeply materialist concept of nature and linked it indelibly to human labor. He writes:

[1]abour is, in the first place, a process in which both man and Nature participate, and in which man of his own accord starts, regulates and controls the material re-actions between himself and Nature... By thus acting on the external world and changing it, he at the same time changes his own nature. (Marx, 1867: 257)

Marx outlines how particular 'economic epochs' can be defined by the instruments and processes through which humans interact with others and with the material conditions of their existence (Chandel, 1979). Non-human nature and humans are in continual dialectical interplay and both are transformed by each other through the process of labor (Parsons, 1977). History then, can only be understood through examining humans in terms of their work: "with what they produce and with how they produce" (Marx and Engels, 1965: 32). The corresponding ideologies of a particular epoch will coincide with "a definite form of activity" (Marx and Engels, 1965: 32).

It follows that to explore ideologies of non-human nature it makes sense to examine the particular 'form of activity' that it corresponds to. This is a way of exploring ideologies on non-human nature as they developed in dialectical interplay with a definite historical mode of production. Throughout this paper I will attempt to develop an understanding of particular ideologies as they are linked to particular modes and relations of production.

Central to Marx and Engel's concept of consciousness is the 'human-labor' process; that is, the "way in which men produce their means of subsistence" (Marx and Engels, 1965: 31). For Marx, an epochal 'mode of production' corresponds with human consciousness and so consciousness is always social; it has a real material connection to a reality external to itself (Chandel, 1979). According to Marx and Engels, "The production of ideas, of consciousness, is at first directly interwoven with the material activity and the material intercourse of men, the language of real life" (Marx and Engels, 1965: 37).

However, while humans are conditioned by the productive forces of their material existence they are also able to act upon them. For Marx and Engels (1965), humans are not constrained by nature's laws (as animals are): rather they are conscious beings able to interact with nature to "produce their means of subsistence" (p. 31). Human 'consciousness' is a critical part of Marx and Engel's philosophy. For Marx and Engels it meant that humans are primarily social, active and thinking beings.

\section{Philosophy and nature}

The significance of philosophy to ideas about the natural world cannot be underestimated. Indeed, it is difficult to imagine any theory or idea about nature that does not have an underlying metaphysical foundation. Eugene Hargrove (1989) argues that there are two traditions in philosophy that have influenced Western environmental thought. These include classical Greek philosophy and early European philosophy. Hargrove (1989) maintains that classical Greek antiquity and post-Socratic Greek philosophy, in particular that of Plato and Aristotle, have had a strong influence on later thought on nature.

The ancient Greeks believed that Kosmos is the origin of the world and that customs were timeless (the way things have always been). Thus, history is a modern concept and is based on the idea of humanity and changes in conventions and customs over time (Zhang, 2006). The word humanitas was absent in classical Greek antiquity, and the current emphasis on 
the separation of nature and culture was not made. However, Aristotle interrupted this with notions of human superiority over other living creatures (Zhang, 2006). When history becomes a social process (not natural or 'the way things are') and nature regarded as separate from social/cultural processes, then the dualism of culture/nature is born.

Wenxi Zhang (2006) builds on this, arguing that, "the separation of history and nature has become an existential tension between the modern and the ancient" (p. 636). By this he means that in ancient times nature and culture were not separated, and that the birthplace of nature as an idea began in ancient Greece (Zhang, 2006). Bridging the ancients and the moderns is the concept of history, which was based on the "metaphysics of non-history" (Zhang, 2006: 637).

The discussion of nature by modern Western philosophers has included concerns to do with the moral rights of non-human life forms and a holistic land ethic (e.g. Aldo Leopold), as well as the intrinsic versus extrinsic value placed on nature. The importance of the application of philosophical thought to the problem of nature is also stressed by Holmes Rolston (1999), who makes the case that human intervention in and management of nature is a problem that can only be addressed through "a metaphysics of nature and of human nature" (p. 143). Increasingly, Rolston (1999) argues, humans see themselves as "planetary managers", and yet many of those involved in this (such as economists) are not at all certain about "what they believe" (p. 143). This is a matter to be addressed by philosophy and ethics, and includes questions such as whether nature has 'intrinsic value'; whether through transforming nature we are also causing its demise; and what are the consequences of living in a post-natural and modified world (Rolston, 1999).

These themes have long provided philosophical gristle. But is Western academia up to the challenge? Yrjo Haila (2000) claims that the nature/culture dualism is entrenched in Western metaphysics and has led to a conceptual prison (p. 158). This, she argues, has a detrimental effect on environmental thought as it leads to the objectification of nature instead of a focus on the contexts within which nature and culture belong together.

Judith Alder (2006) also argues convincingly that our understanding of nature is limited within academia. She argues that most academic historians of environmentalism are locked into the "secular university- based intellectual culture" and fail to appreciate the diverse and discordant philosophies of humans and nature from ancient times (Alder, 2006). In particular she argues that by the fourth century, diverse schools of spiritual thought had constructed 'desert' or 'wilderness' as pure spaces that were a refuge from human settlement. According to Alder (2006), in the third century Origen (as Christianity's first major theologian) saw the 'desert' or 'wilderness' as a pure place where God is more familiar (Alder, 2006: 15).

\section{The great divide: Nature and culture}

The claim that nature and wilderness have an 'intrinsic' value (independent of their extrinsic value and related ideological constitution) is, as demonstrated in the above section, a philosophical claim often made by environmentalists. However, this claim is based on the ideological division between humans and nature, which is premised on troubling binaries. These include culture/natural; subject/object; man/woman; and mind/body dualisms (Merchant, 2005). These dualisms have been explored (especially in eco-feminist literature) for the insights into a misogynistic Western culture that drawing parallels can afford. 
Haila explores the culture/ nature dualism in more detail. According to Haila (2000):

Culture may be viewed as an agent that actively strives for domination over nature, or as a malicious tumor that tends to grow and exceed the limits set by nature. Nature may be regarded as a source of hardships and catastrophes that needs to be mastered by human rational action or, alternatively, as benign providence that offers advice. The common denominator of all these varieties is that culture and nature are opposite sides in a dualism. (Haila, 2000)

The separation of humans and nature is an anthropocentric ideological position and one that tends toward a posture of what Jim Mason calls dominionism over nature (Mason, 2006). According to Mason, dominionism is the ideological backbone of Western culture, and is the view that "human beings have a God-given power or right to use and control the living world for their exclusive benefit" (Mason, 2006: 180).

This attitude of superiority has been challenged by radical ecology. The theme of interconnectedness between humans and non-human nature is one that is frequently evoked in radical ecology literature (Argyrou, 2005: 54). Early arguments of this kind in the 1970s can be located in the work of Arne Naess, who called for a rejection of "man-inenvironment image in favour of the relational, total-field image" (Naess, 1983: 343). Naess (1983) called this 'new' way of looking at non-human nature 'ecosophy', and argued that it held normative principles to guide human action. This implies a non-exploitative premise for human relationships with the non-human world, and recognition that all life forms demand equal respect and right to life.

Likewise, eco-feminists such as Vandana Shiva (2005) assert that the Earth is a community of all beings and that it should be regarded as a commons rather than a global supermarket. This use of metaphors to describe the modern complex relationship of humans with the Earth is echoed in the work of Val Plumwood (2002). Plumwood (2002) uses the metaphor of the Titanic to describe the Earth and our collective human journey. She stresses that the boat represents an "ecological world on which we are all passengers" (p. 2). Plumwood's argument is that humans need to value the non-human world and recognize their dependency on it (Plumwood, 2002: 3).

However, Plumwood argues that our journey as humans on Titanic Earth is stricken. We have, Plumwood writes, "received the iceberg warning" (Plumwood, 2002: 1). The Earth, like the Titanic, is on a course toward crisis. This is well documented and will only be briefly discussed here. Shiva (2005) identifies the main themes of concern regarding environmental degradation and exhaustion of resources. These include: a reduction in the Earth's biodiversity because of the reliance on industrial agriculture which favors monoculture agricultural crops; toxic pollution due to the use of chemicals in agricultural production; depletion of water and energy resources; desertification and global warming.

Earth's course toward the iceberg is a warning cry that has been uttered in environmental thought as early as 1864. Uncharacteristically for the times, George Perkins Marsh was mindful that the Earth may be reduced to "impoverished productiveness" (Marsh, 1864, cited in Hughes, 2006: 31). This focus on the Earth's productiveness underscores a utilitarian approach to non-human nature. Thus, while Marsh was concerned about the impact of environmental destruction on the Earth, it wasn't for its own sake but rather because of how the declining productivity would affect humans. Devall and Sessions call this a "narrowly utilitarian scientific/technological management" approach, and argue that it has dominated the conservation movement (Devall and Sesions, 1984: 293). The desire for 
preservation of 'wilderness' has been distinguished from interests in managing non-human nature to conserve resources (Thompson, 1983).

Radical ecology, on the other hand, places emphasis on the value of human and nonhuman life for its own sake. This represents a shift from a worldview of nature as an object to be used (a utilitarian view), to one of nature as vital and sacred (Argyrou, 2005). According to Argyrou (2005), this shift in perception represents a key shift in ontological positioning in the West. Thus, radical ecology has presented a challenge to the assumption that nature and society are separate (Argyrou, 2005).

Radical ecology has a range of predecessors including eighteen century German Romanticism and its call for a recognition and idealization of nature as "pure and authentic" (Keith, 2011). This includes the work of Rousseau, who will be discussed in more detail later. At this point it is sufficient to say that he represented Romanticist resistance to the social ills of a rapidly developing urban culture in Western Europe. Keith (2011) describes this environment as one that:

...swelled with suffering and squalor... Satanic mills destroyed rivers, the commons of wetlands and forests fell to the highest bidder, and coal dust was so thick in London that the era could easily be deemed the Age of Tuberculosis. In Germany the Rhine and the Elbe were killed by dye works and other industrial processes" (Keith, 2011, p. 115).

Marxist thought has also challenged the divide between nature and humans and analyzed the ways 'nature' is ideologically constructed in capitalist society (Castree, 1995; Schmidt, 1971; Smith, 1984). Marx's materialist and dialectical philosophy of nature offers a means for understanding human relationships with nature in a deeper sense than merely the means for survival. Marx believed that, "the physical and mental life of man, of nature, are interdependent means simply that nature is interdependent with itself, for man is a part of nature" (Marx, cited in Bottomore, 1963: 127).

It is of interest that Marx and eco-Marxist theory has been critiqued by radical ecologists for its situatedness in Enlightenment thought itself. Critics have argued that Marx did not take account of the world's "natural limits" (Foster, 2000: 1). He has also been criticized for working within the rationalistic neo-Cartesian ideological framework, which deep ecologists see as anthropocentric and antithetical to the eco-centric worldview they champion.

Marxism is considered by post-structuralists to be a 'grand-narrative' of the Enlightenment eco-feminists such as Carolyn Merchant (2005), and critique Marxian theory for its human-centered orientation and endorsement of science and technology in the pursuit of human progress. In contrast, the eco-centric ethic is contrasted as regarding the natural world (including both animate and inanimate aspects of the environment) as having 'intrinsic value'.

However, Biro (2005) cautions that this reading of Marx leaves out important points. The historicization of ideology in Marx means that 'progress' and 'mastery over nature' need to seen in relation to particular social relations of production. For Biro it is debatable that "Marx's view of human fulfilment under socialism is necessarily predicated on 'nature domination"” (Biro, 2005: 91). Marx also held a relational view of nature. He argued that humanization of nature occurs when man's consciousness has evolved to create objects from nature (Chandel, 1979: 98). 
In transforming nature man transforms himself, and thus nature and man are one. David Pepper expresses this sentiment well:

Through changing nature and making things, we have changed ourselves into creatures who can appreciate the beauty of what we create; buildings, machines, art. We have developed our subjective senses - our feelings and emotions... included in all this are our intellectual senses. As we transform nature we get to know nature's laws in order to transform nature more effectively and usefully. As this happens we develop our own intelligence. (Pepper, 1993)

This process is linked to Marx's concept of 'species being'. According to Marx, humans produce from nature independently of physical needs. That is, work is the process through which men produce according to the "laws of beauty" and "he sees his reflection in a world which he has constructed" (Marx, cited in Bottomore, 1963: 128).

However, according to Marx, under capitalism this phenomenon leads to the objectification of humans and the loss of themselves as human subjects in the world. Humans have become commodified through their labor. The product of the worker's labor is alienated from him because it is only a means to ensure his physical survival (wage labor) (Marx, cited in Bottomore, 1963). Marx writes that, "alienated takes away the object of production from man... his inorganic body, nature is taken from him" (Bottomore, 1963: 128).

\section{Philosophical illusions}

Part of what Eric Fromm calls the 'great illusion' of the industrial age has been the quest for knowledge and domination of nature (Fromm, 2007). This indicates the need for a critical and timely re-examination of what Fromm calls the two modes of existence -having and being (Fromm, 2007). Fromm (2005) discusses the 'second industrial revolution' as a stage where humans become completely 'alienated' from themselves:

$\mathrm{He}$ is programmed by the principles of maximum consumption, and minimal friction. He attempts to relieve his boredom by all kinds of consumption including drugs and sex. This, and possibilities of neurologically and physiologically produced changes in his feelings, in addition to the manipulation of his thought processes by suggestive methods, will be used to provide man's smooth functioning as a part of the megamachine. (Fromm, 2005: 51)

This "change in human existence", from human to machine, is a process of alienation from nature (Fromm, 2005: 52).

It is, as Rousseau would contend, a corrupted existence. Rousseau describes the state of 'natural man' to be one of self-respect and compassion (Jack, 1978). Rousseau argues that the natural human passion for pity is a "natural repugnance at seeing any other sensible being, and particularly any of our own species, suffer pain or death" (Rousseau, 1979). The horror of the dual picture painted by both Fromm and Rousseau should give pause for thought. If humans increasingly become alienated from their existence as thinking, compassionate and active beings, then we are left with passionless 'machine-bodies', fulfilling the dictates of capital. Donna Haraway (1991) echoes this concern. She argues that the division between humanity and machines is becoming increasingly obscured. Furthermore, she writes that, "Our machines are disturbingly lively, and we ourselves frighteningly inert” (Haraway, 1991: 152). 
The oppression of humans through capitalist processes is linked to the exploitation of nature. The two are intricately connected, and modern science is staking its claim in what may well be the last vestige of human resistance: "the invention and reinvention of nature [is] perhaps the most central arena of hope, oppression and contestation for the inhabitants of planet earth in our times" according to Haraway (1991: 1).

People living in advanced Western capitalist societies become subjects of its horrific philosophical trajectory, internalizing and normalizing its brutal assumptions. Take, for example, the notion of 'perfectionism' coined by Paola Cavalieri (Cavalieri, 2001). 'Perfectionism' refers to the thinking that ascribes higher status to certain characteristics in humans (Cavalieri, 2001). Cavalieri argues that this philosophic tradition is over 2000 years old and has justified using:

... nonhuman animals as a means to our ends. We kill them for food, we use them in our work and entertainment, we employ them as tools in research of all kinds, and it is rare that we pause to ask ourselves whether our behaviour is morally justifiable. (Cavalieri, 2001: 3)

This attitude toward animals is often tempered with a concern to militate against unnecessary suffering, but Cavalieri suggests that this is a negligible constraint when held up against the broad definition of human needs. There are also deep contradictions within this paradigm. While companion animals may be coddled and protected by law against mistreatment, many farm animals are routinely denied the most basic of their physical and emotional needs (Grandin, 2009).

The key question becomes how do particular ideologies about nature become accepted and seen as normal? If we are to accept Rousseau's proposition that the human's primal and original nature encapsulated the right impulses, including the "innate repugnance at seeing a fellow-creature suffer", then it seems we are a long way from our primal selves (Rousseau, 1979). Humans have become alienated from their instincts of love of self and love of other (Sahakian and Sahakian, 1974).

\section{Alienation from nature: The importance of the work of Rousseau and Marx}

Alienation from nature is a significant concept with educational implications. The work of Jean-Jacques Rousseau (1712-1778) illustrates a Romantic eighteenth century view of nature as good and humans' natural state as right. For those thinkers in the modernist era such as Jean-Jacques Rousseau and Karl Marx, the significance of nature to their philosophy of 'man' was paramount.

The importance of nature to human existence is an insight developed by the Romantics. It is based on an ideology of nature as an integral element of being human. Rousseau (1979) argued that the natural state was good and argued for a unity between humans and nature. For Rousseau humans were naturally free, and he argued vehemently against their alienated existence under civilization. Civilization was regarded by Rousseau as the root of all inequality and evil.

Rousseau reacted against the 'possessive individualism' of bourgeois society and did not regard economic growth as desirable for human development (Biro, 2005). Furthermore, he argued that bourgeois society was corrupt and advocated that humans should live according to nature. To this end he believed in an education for children that allowed them to discover their true self, including the basic needs of the human mind and body. 
For Rousseau then, there is a universal human condition which humans became alienated from through social processes or convention. He argued that all humans are born equal and innocent, but through social processes humans become "mannered but manipulative role player[s]". For Rousseau, the human is born with a natural love of self (amour de soi or amour propre) (Rousseau, 1979: 92). If self-love is allowed to develop through immersion in the natural world it will continue to radiate toward family, then community and country, and finally God (Rousseau, 1979). Nature is thus seen as the locus of all reality and should form the basis of education.

Emile is a fictitious male character in Rousseau's didactic novel. He served to demonstrate Rousseau's educational proposition that the child needs to interact with non-human nature (wild; land) independently from human theories and bodies of knowledge that construct it in terms of "inert highly verbal information remote from nature" (Gutek,1998: 72). Rousseau advised parents to "[o]bserve nature and follow the path it maps out for you" (Rousseau, 1979).

Marx's discussion of alienation has a philosophical context (Bottomore, 1963). Like Rousseau, Marx also held that ontologically, 'Man' is a 'free, conscious being', but through exploitative relations of production becomes alienated from his Being. $\mathrm{He}$ becomes alienated from his being as a human and from human nature itself. According to Fromm (2004):

Marx's aim was that of the spiritual emancipation of man, of his liberation from the chains of economic determination, of restituting him in his human wholeness, of enabling him to find unity and harmony with his fellow man and with nature. (p. 2)

Burkett argues that Marx's writings provide a deeper understanding of how capitalism, as a historically contingent mode of production, socially constructs the concept of nature (Burkett, 1999). "Marx's treatment of natural conditions possesses an inner logic, coherence and analytical power that have not yet been recognised, even in the ecological Marxist (or "eco-Marxist") literature" (Burkett, 1999: 1).

The following sections will explore ideologies of nature and attempt to locate them historically. These sections demonstrate and the increasing dominance of misogynistic and destructive ideologies of nature in modern times.

\section{Animism and organic ideologies of the 'nurturing mother'}

Indigenous ideologies of nature as 'Mother Earth', or 'Earth Worship' are sometimes referred to in academic literature as 'goddess cultures'. They have given voice to ecofeminist scholarship and provide a platform to argue against patriarchal exploitation of nature and women. Drawing links between the exploitation of nature and women by man, eco-feminists evoke the Earth Mother as the basis for a new ethic and unity with nature (Collard and Contrucci, 1988).

Collard and Contrucci's research suggests that "European-based societies receive their notion of Mother Earth from pre-Hellenic Greece influenced by Crete, Ancient Anatolia and the Near East, as well as the powerful Celtic tradition which extends in a broad sweep from northern Ireland to Spain" (Collard and Contrucci, 1988: 8). Originating in Mesopotamia during the Paleolithic Age (25,000-15,000 BC) and spreading throughout Europe, Africa, Asia and the Near and Middle East, this female-centric outlook has persisted until AD 500 and is still evident amongst some indigenous communities (Collard and Contrucci, 1988). 
Female-centered positions are an important counter to the dominance of what ecofeminists consider misogynistic, patriarchal and destructive ideologies toward nature.

There is a tendency amongst scholars to reduce the worldviews of ancient peoples to a 'first stage' in the historical development of civilization. For example, Foss (2009) writes:

[i]n this first stage, nature is seen as both a friend and an adversary. The first imperative of all organisms is the struggle to survive. The beauty of nature is recognised, especially in terms of the abundance of game or the fertility of the ground, but so is the destructiveness and fearsomeness on nature. Nature is both loved and hated. It is in this first stage that agriculture, civilisation and industrialisation are eventually attained. (Foss, 2009: 17).

Such a view, while recognizing human interaction with the objective material conditions of existence as important in the process of historical development, negates to perceive the complexity of this process. Human 'progress', ideologies and struggle are seen in terms of interaction with the non-human world and the challenges this poses. This binary opposition of "[n]ature giveth, and nature also taketh away" (Foss, 2009: 15), refuses to regard the nonhuman world in any other terms than something 'outside' of humans that we struggle to 'liberate' ourselves from. Thus ideologies are a mere reflection of these struggles rather than embedded in the real material process of existence. It sees the development of 'tools', 'technology' and 'civilization' in progressive terms (Foss, 2009).

Even more worrying than the simplification of ancient worldviews of Mother Earth is the modern interpretation of it in patriarchal ways. 'Mother Earth' represented in these terms loses its original meaning. As Collard and Contrucci (1988: 4) argue, current reference to 'Mother Nature':

... retains a vague connotation of uncontrollably punishing weather... It stirs up fantasies of conquest in the language of hunters who claim to 'love' nature even as they kill her animals. It obsesses all manner of scientists who 'love' her to death in an attempt to 'penetrate' and understand all her 'secrets'.

'Animism' is another term referred to by scholars, particularly anthropologists, when describing ancient ideologies of nature. It is a term coined by E.B. Tyler in his anthropological work Primitive Culture (Bird-David, 1999). Characteristic of animism is a reverence for animals and nature. Merchant (2005) contends that in ancient times and into the Renaissance, there was a world view of the cosmos as alive. Aldo Leopold and James Lovelock are recent exponents of this idea, and convergence can also be found in indigenous and certain aspects of Asian thought (Kinsley, 1995). However, in this section I will explore 'animism' of the ancient worlds.

'Animism' is an 'existential' statement of a people's experience. According to Carolyn Merchant, as late as $1500 \mathrm{CE}$, Europeans, and other people, lived in close daily interaction with the non-human world (Merchant, 2005). The individual was subordinated to the communal interest in all spheres of life, including the "family, community and state" (Merchant, 2005: 76). Research into Earth Mother beliefs reveals a 'matriarchal' figure who is giving and nurturing and who embraces earth spirits in her being. She is alive; 'vital life' existed in the cosmos, even in stones (Merchant, 2005). As Gaard (1998: 23) says, "[n]ature is perceived not as a force to be dominated but rather as a living being from which all life came and to which offerings and devotion were given". Nature within this ideology is sacred and to be revered. 
An important point about ancient ideologies of nature is that they have a 'relational epistemology' (Bird-David, 1999). Merchant (2005) argues that this 'organismic theory' of Mother Earth as a living entity had a normative effect on people's behaviors. Merchant (2005: 78) writes:

One does not readily slay a mother, dig into her entrails for gold or mutilate her body... As long as the earth was considered to be alive and sensitive it could be considered a breach of human ethical behaviour to carry out destructive acts against it. For most traditional cultures, minerals and metals ripened in the Uterus of the Earth Mother, mines were compared to her vagina.

The nurturing Earth is a metaphor prevalent in ancient worlds and amongst traditional cultures. It continued into the Renaissance period-but over this time a shift began to occur that split the inanimate and the animate, divided the human and non-human into social and natural categories. Merchant has argued that the removal of the divine from nature resulted in her death (Merchant, 2005). In the next section I will explore how shifts in Christian thought led to the idea of dominion over nature.

\section{The Fall and the Flood: Christian ideologies of nature}

The Judeo-Christian orientation, and in particular the Genesis creation myth, is one source of the benevolent nature ideology. The 'biblical garden' of God's creation is lavishly described by scholars as a place of harmony and contentment as animals and humans co-existed perfectly (Delumeau, 1995). In Genesis 2.8 it states that:

And the Lord God planted a garden in Eden, in the east, and there he put the man whom he had formed. And out of the ground the Lord God made to spring up every tree that is pleasant to the sight and good for food. The tree of life was in the midst of the garden and the tree of the knowledge of good and evil. (Genesis 2:8, English Standard Version)

In this saga non-human nature takes center stage as a sacred and pre-human construct. The Garden of Eden myth is a narrative of paradise found and lost, of both freedom and domination and of innocence and sin (Kurtz, 1979). After Adam and Eve's fabled fall from innocence (after partaking of the fruit of the Tree of Knowledge of Good and Evil), and subsequent banishment, the Garden of Eden is said to be guarded by fiery swords to prevent humans re-entering. Genesis recalls God's punishment: "He drove out the man, and at the east of the garden of Eden he placed the cherubim and a flaming sword that turned every way to guard the way to the tree of life" (Genesis 3:24, English Standard Version).

Will humans ever be able to dodge the sword and re-enter the terrestrial paradise? The fall marked a new state of humans in nature. The story of the Fall recalls that Eve, who was fashioned last of all (after Adam), picked a forbidden fruit from the Tree of the Knowledge of Good and Evil and God banished her and Adam from the Garden of Eden. God admonished Adam and told him:

Cursed is the ground because of you; through painful toil you will eat food from it all the days of your life. It will produce thorns and thistles for you and you will eat the plants of the field. By the sweat of your brow you will eat your food until you return to the ground, since from it you were taken; for dust you are and to dust you will return. (Genesis 3:17-19, English Standard Version)

Henceforth humans were mortal beings of the Earth, yet not one with nature but subjected to a wild and untamed landscape with which they must endlessly toil to survive. 
An oppressive and tyrannical view of human relationship with animals begins to emerge. For example, in Genesis 9 after the flood the Earth is a place of domination and fear for animals:

The fear of you and the dread of you shall be upon every beast of the earth, and upon every fowl of the air, upon all that moveth upon the earth, and upon all the fishes of the sea. Into your hand are they delivered. Every moving thing that lives shall be food for you. And as I gave you the green plants, I give you everything. (Genesis 9:2, English Standard Version)

The Judeo-Christian tradition has had a strong influence on Western thought. Sandie Suchet (2002: 142) writes that:

[s]tatic, naturalised boundaries between what is seen as 'culture' and 'nature', 'human' and 'animal' are fundamental in Judeo-Christian traditions about the creation process. Man's ability to name separates him from, and makes him more powerful than 'living creatures' (and women).

During the Renaissance period there was a shift in ideologies of nature, although the organic view of nature as alive was still present. During the Renaissance the view of humans as central to the world and as the master of nature was established. As Kinsley (1995) notes:

... in almost all Christian thought prior to the Renaissance ... the superiority of human beings over all other creatures tended to be tempered with an emphasis upon the creatureliness of humans and their utter dependence upon God. In the Renaissance, an increasingly elevated view of human beings came to be expressed... [I]t was human destiny and nature to master the creation. (Kinsley, 1995: 126)

This form of atheism establishes the existence of Man as Ego and sole divinity and also meant the annulment of God. This divestment of Man from religion is the basis of Humanism. The dominant view of nature encapsulated in these writings is that God created the physical world but it is not divine (Kinsley, 1995). According to Merchant (2005: 31)

[b]eginning in the seventeenth century and proceeding to the present, New World colonists have undertaken a massive effort to reinvent the whole earth in the image of the Garden of Eden. Aided by the Christian doctrine of redemption and the inventions of science, technology and capitalism... the long term goal of the recovery project has been to turn the earth itself into a vast cultivated garden.

Transformation of the Earth into a managed cultivated garden brings the concept of wilderness into sharp relief. The humanization of nature has resulted in what many postmodernists have referred to as the death of nature (Rolston, 1999).

\section{Rationalist ideologies of nature}

The breakup of feudal states was followed by the rise of capitalism from the sixteenth century onwards. This new economy was based on increasing economic trade, the development of technology, the establishment of markets in inorganic metals, the use of non-renewable energies and the emergence of a working class of wage-earners. Ideologies that developed in response to this include logical positivism and Cartesian objectivism-hallmarks of the Enlightenment. 
The Enlightenment period during the seventeenth and eighteenth century emphasized the individual, free will and the development of reason. Logical positivism has, since the Enlightenment of the eighteenth century, dominated Western thought. It privileges truth-statements and verifiable facts about the natural, economic and social world (Merchant, 1995).

Thus a central challenge to the organic view of nature described earlier was also made by the developing fields of science, physics and mathematics. During the Renaissance period scholars that developed the later modernist and Enlightenment views of nature include Francis Bacon, René Descartes and Isaac Newton (Kinsley, 1995: 127). Francis Bacon (1561-1626) was an early scientist. He claimed that the aim of the scientist is to torture nature's secrets from her. Nature was to be "hounded in her wanderings", "put into constraint", "bound into service" and made into a "slave" (Capra, 1982). René Descartes (1596-1650) built on the Aristotelian dichotomy of subject and object. In Cartesian logic 'nature' is seen as passive, as an object that is separate from man, just as the body is separate from the mind. Isaac Newton (1642-1727) argued that nature should be described by rationally understandable laws. The stress was on measurement and objectivity. Changing ideologies of nature reflected a shift from nature as alive and organic to nature as made of matter, nature as machine and nature as passive and inert.

The Cartesian rationalist position dividing humans and nature is invoked by Plumwood (2002) to explain anthropocentric worldviews that advocate minimal departure from current status quo. The rationalist economic regime, supported by neo-Cartesian views, aims to "extract the most from the other who is the resource" (Plumwood, 2002: 159). Her argument that current rationalistic neo-Cartesian ideological dominance has led to 'false' understandings of the location of humanity within nature (separate from nature) resonates with Selby's insights into Western worldviews. According to Selby (2002), mainstream Western thinking constitutes a worldview with regards to the environment that is "underpinned by notions of separation, otherness and domination." He claims that these understandings have been shaped by seventeenth and eighteenth century scientific and philosophical ideologies (Selby, 2002: 78). The philosophical underpinnings Selby refers to are based on modernist ideals that celebrate rationality (or transcendent reason) and a belief in the scientific method. They constitute central dominant tenets of Western culture and are central to humanist liberalism today (Selby, 2002).

The seventeenth and eighteenth century was a time that great significance was placed on naming, classifying and ordering the natural world. The Endeavour voyage of 1769, captained by James Cook, was a botanical exploration of great significance for the developing fields of taxonomy and botany. The botanical party on board was led by Joseph Banks (1743-1820) and collected flora and fauna from the South Seas and Australia - areas that were previously unchartered by the Western world (Allen, 1990). David E. Allen (1990) remarks that the results were outstanding:

For also toiling on the conveyor-belts are the plant and animal taxonomists and the connoisseurs of natural history art. From the Endeavour voyage alone over 30,000 specimens survived to return with Banks, among them perhaps as many as 1400 plants new to science, extending the known flora of the globe (as enumerated by Linnaeus in the Species Plantarum) by no less than a quarter.

Bottled flora and fauna of such voyages are now stored in draws and shelves of museums; dead, pickled and inert, awaiting the further objectification by the scientist. 
One of the most disturbing tenets of the rationalist ideology is the view that non-human nature and animals are inferior to humans (Plumwood, 2002). Plumwood (2002) argues that this ideology relies on 'the construction of the 'other' through binary oppositions such as mind/body and human/animal." The forms this takes under modernity include the use of "animals- as-living-tool" in scientific experiments (Collard and Contrucci, 1988). Such violence is not only legitimated but celebrated through publication of the ensuing research material and funding (Collard and Contrucci, 1988). The commodification and objectification of animals and non-human nature as 'other' takes its extreme form in the patenting of non-human nature forms including plants and animals.

\section{Western capitalist ideologies of nature}

As noted earlier, the societies that existed pre-capitalism did not differentiate between nature and humans. But under capitalism nature and society became antagonistic and fragmented forces (Pepper, 1993: 110). Within capitalism non-human nature becomes objectified in the form of a commodity (Pepper, 1993: 108). The commodification of non-human nature is well developed in Marx's work. According to Marx, capitalist production can be distinguished by the production of products as commodities. As "Being a commodity is the dominant and determining characteristics of its products" (Marx, 1894: 1178).

The commodification of products has included 'natural resources', further problematizing the deep-green call for 'intrinsic value' in nature. Using the concept of 'use value', Marx (1867) builds an understanding of the productive processes of capitalism. A 'use value' becomes a commodity and acquires 'exchange value' through a social process (Marx, 1867). According to Marx, direct relation between objects and man reveals their use value. But the exchange value is independent of their use value. Thus, "so far no chemist has ever discovered exchange value either in a pearl or a diamond" (Marx, 1867). The commodification of non-human nature in this way is supported by utilitarian views of nature as having extrinsic value.

Capitalist ideologies that construct land as having a 'use value' have also been used to support notions of progress and development. In particular, Plumwood (2002) explains how European colonization of indigenous peoples and their lands was justified by ideologies of superiority. Indigenous peoples were regarded as 'primitive' and closer to animals and children. Their lands were constructed as 'empty' and 'unused'. Furthermore, through naming what were considered 'discoveries', early Western botanists divest the 'thing named' of its history and meaning (Tuhiwai Smith, 1999).

Ideologies of dominance and control originating from Western Imperialism have in some cases been softened by the language of management. Suchet argues that notions of conservation management and wildlife management are predicated on notions of control and domination (Suchet, 2002). Suchet uses the example of National Parks that are often:

...presented as exemplars of nature in all its glory, unspoilt and pristine. Rendered invisible in this discourse are management mechanisms such as roads, fences, constructed water points, wildlife counts, reintroduced animals, culling quota, feral animal baits and tourist infrastructure, as well as experiences of interaction and dispossession. (Suchet, 2002: 148)

The notion of 'ecosystem services' provides a compelling illustration of the articulation of 'conservation' discourses with those of the market. 'Ecosystem services' is a metaphor for 
humanity's dependence on the natural world (Redford and Adams, 2003). The utilitarian values placed on 'ecosystem services' by mainstream sustainability politics underscores an ideological commitment to an anthropocentric worldview. For example, the Millennium Ecosystem Assessment Synthesis Report defines ecosystem services as: "the benefits people obtain from ecosystems. These include provisioning, regulating, and cultural services that directly affect people" (Millennium Ecosystem Assessment, 2005).

Discussion of 'markets' in ecosystem services is now commonplace. Ecosystems have become subject to economic mandates such as pricing or valuation. For example, Kent Redford and William Adams (2009) (both wildlife conservationists) argue that, "[t]here will be winners and losers in markets for ecosystem services... As people annex ecosystems and adapt them to maximise revenue flows, collateral damage to biodiversity will be unnoticed or discounted" (p.786). Redford and Adams (2009) rightly point to the limitations of regarding nature in solely market economic terms only: the loss of biodiversity being regarded as collateral damage; the growth of "nature manipulation" industries (carbon capture through artificial trees; genetic modification; biomimicry). They argue that although framing markets in terms of ecosystem services provides a stimulus for conservation, it fails to value nature in any other terms but its usefulness to humans.

\section{Education}

From the above discussion several educational problems emerge. For example, does the Western education system (dominated as it is with upholding rational and scientific thought), function to dehumanize and alienate students further from nature and from themselves as human beings in the world? In this regard, appreciating the critical role of the school in Western society in transmitting and hence perpetuating dominant ideological constructs is important. John Ahier (1974) argues that ideologies function to "maintain the status quo' by inhibiting action, by giving a false picture, or by presenting as objective an implicit value judgement" (p. 214). Thus, the school structure can be seen to reflect and reinforce the ideologies and implicit values of wider society.

Rousseau and other naturalists thought that the answer lay in a form of naturalist education as nature is the "basis of ethical relationships", and expresses a beneficent and universal order (Gutek, 1988: 71). Certainly some of the principles underlying Rousseau's vision of education such as the fostering of students' natural abilities and curiosity should be upheld. Rousseau argues that the curriculum 'comes' to the child through immersion in nonhuman nature. This may be worth revisiting as a critical space to re-consider what constitutes education and how we can counter the domesticating features of the current Western school system.

Finally, the cultivation of a 'geocentric' or 'solar ethics' in education supports a relational view of the world (Peters and Hung, 2009). Michael Peters and Ruyu Hung argue that this could be the basis for a new paradigm in education, in that it would constitute a move away from an anthropocentric posture toward one based on systemism and ethics. They argue that, "the primary significance of solar ethics is to call for an imagination of taking the solar system as an ethical frame of mind which means the solar system may inspire us to reconceive human moral responsibility, decision and action" (p. 327). 


\section{Conclusion}

And so we return to Rousseau and his proposition that Emile should be educated in union with nature. Rousseau's philosophy of natural man underscores his position on the human existential problem. The true meaning of human existence can be found in nature.

It is now possible to tentatively formulate a response to the question: is Emile in the Garden of Eden? The Garden of Eden, as we have seen, is guarded by angels with fiery swords. The only way Rousseau is going to break through that border is through Emile's human capacity to love and reason. Fromm (2005) has shown how this is a solution to gaining unity with nature. He writes that within these strands of thought, which form the essence of the Western tradition, "[m]an's task is to develop his humanity, and in the development of this humanity he will find a new harmony and hence the only way in which he can solve the problem of being born" (p. 76). The harmony Fromm speaks of is with "himself, with his fellow men and even with nature" (p. 76).

And what of the Earth as the ship the Titanic, discussed earlier in this paper (Plumwood, 2002)? Plumwood advocates democratic cultural change to help us "acknowledge our ecological imbeddedness" before we go down with the ship (Plumwood, 2002: 3). Ecological awareness must surely include a developing compassion and awareness of a commonality in sentience between humans and non-human animals. Mark Bekoff (2007) claims that animals possess, "moral sensibilities and these are the evolutionary precursors to our own moral behavior". (p. 83). Yet when our moral behaviour and social character orientation is shaped by what Fromm (2007) calls the 'having mode', it would appear the compassion is being jettisoned in favor of selfishness. This will have dire consequences for Plumwoods (2002) plea for democratic cultural change and awareness of our ecological embededness.

So entrenched is the ideological framework that calls for human domination, mastery, management and control of all that is 'not human', that many have lost the empathy Rousseau saw as essential to being. To be in this sense is to justify cruelty and destruction in the name of progress, technology and science. Using animals for experiments is one example of this. Collard and Contrucci (1988) describe animal experimentation as mad and sadistic. It's not just about animal rights. It's also about what it means to be human in the world. To be human is to experience a world where humans are not alienated from themselves and from nature-and as I have attempted to show, the two are deeply connected.

Erich Fromm (2005) argues that a geocentric positioning of humans is now possible. He writes, "a picture of Earth has been made available from distant space, from the lunar desert, and the sheer isolation of the Earth has become plain" (p. x). Peters and Hung (2009) extend this line of thought to 'solar ethics', arguing, like Fromm, that humans are part of a bigger solar system, dependent on forces such as the sun for life. Solar systemism can lead to a view of humans and nature as existing on the same continuum, rather than separate. This view sees the sun as the center of all life on Earth. Peters and Hung write, "[s]olar ethics is a frame that will help to re-position humans within nature and lead to a more sustainable world view" (p. 321). This line of thought may hold some promising resistance against dominant ideologies that situate humans and the non-human world in divergent and often antagonistic ways. 


\section{Funding}

This research received no specific grant from any funding agency in the public, commercial, or not-forprofit sectors.

\section{References}

Ahier J (1974) Professions and ideologies. In: Flude M and Ahier J (eds) Educability, Schools and Ideology. London: Croom Helm, pp.211-217.

Alder J (2006) Cultivating Wilderness: Environmentalism and Legacies of Early Christian Asceticism. Comparative Study of Society and History 48(1): 4-37.

Allen DE (1990) Banks in Full Flower. Notes and Records of the Royal Society of London 44(1): $119-124$.

Argyrou V (2005) The logic of environmentalism. Anthropology, ecology and postcoloniality. (studies in environmental anthropology and ethnobiography; v.1). Oxford: Berghahn Books.

Bekoff M (2007) The Emotional Lives of Animals. Novato, California: New World Library.

Bird-David N (1999) "Animism" revisted. Personhood, environment, and relational epistemology. Current Anthropology 40(1): 67-79.

Biro A (2005) Denaturalizing Ecological Politics. Alienationf from Naryure from Rousseau to the Frankfurt School and Beyond. Toronto: University of Toronto Press.

Bottomore T (1963) Karl Marx. Early Writings. London: Richard Clay and Co LTD.

Burkett P (1999) Marx and nature: A Red and Green Perspective. New York: Library of Congress Cataloguing- in- Publication Data.

Capra F (1982) Turning Point. New York: Simon and Schuster.

Castree N (1995) The nature of produced nature: Materiality and knowledge construction in Marxism. Antipode 27(1): 12-48.

Cavalieri P (2001) The Animal Question: Why Nonhuman Aniamls Deserve Human Rights. Oxford: Oxford University Press.

Chandel B (1979) Marxian Ethics Some Preliminary Considerations. New Delhi: Munshiram Manoharlal.

Collard A and Contrucci J (1988) Rape of the Wild. London: The Womens Press.

Cronon W (1990) Modes of prophecy and production: Placing nature in history. The Journal of American History 76(4): 1122-1131.

Delumeau J (1995) History of Paradise: The Garden of Eden in Myth and Tradition. (M. O'Connell, Trans.) New York: Continuum Publishing Company.

Devall B and Sesions G (1984) The development of natural resources and the integrity of nature. Environmental Ethics 6: 293-322.

Dryzek J (2005) The Politics of the Earth: Environmental Discourses. Oxford: Oxford University Press. Foss J (2009) Beyond Environmentalism. A Philosophy of Nature. New Jersey: John Wiley and Sons. Foster J (2000) Marx's Ecology: materialism and nature. New York: Monthly Review Press.

Fromm E (2004) Marx's concept of Man. New York: Continuum.

Fromm E (2005) On Being Human. New York: Continuum.

Fromm E (2007) To Be or to Have. New York: Continuum.

Gaard G (1998) Ecological Politics. Philadelphia: Temple University Press.

Giroux HA (2001) Theory and Resistance in Education: Towards a Pedagogy for the Opposition. Westport, CN: Bergin \& Garvey.

Glover J (2000) Soul of the wilderness. Can we stop trying to control nature? International Journal of Wilderness 6(1): 4-8.

Grandin T (2009) Making Animals Happy. London: Bloomsbury Publishing.

Gutek G (1998) Philosophical and Ideological Perspectives on Education. Boston: Allyn and Bacon.

Haila Y (2000) Beyond the nature-culture dualism. Biology and Philosophy 15(2): 155-175. 
Haraway D (1991) Simians, Cyborgs and Women. The Reinvention of Nature. New York: Routledge. Hargrove E (1989) Foundations of Environmental Ethics. Englewood Cliffs: Prentice Hall.

Harvey D (1982) The Limits to Capital. Oxford: Basil Blackwell.

Hill D (2007) Hegemony and Education. Plymouth: Lexington Books.

Hughes JD (2006) What is Environmental History? Cambridge: Polity Press.

Jack M (1978) One state of nature: Mandeville and Rousseau. Journal of the History of Ideas 119-124.

Keith L (2011) Culture of resistance. In: Mcbay A, Keith L and Jensen D (eds) Deep Green Resistance.

New York: Seven Stories Press, pp.113-192.

Kinsley D (1995) Ecology and Religion. New Jersey: Prentice-Hall.

Kurtz L (1979) Freedom and domination: The garden of Eden and the social order. Social Forces 58(2): 443-465.

Lather P (1996) Troubling clarity: The politics of accessible language. Harvard Educational Review 66(3): 525-545.

Marx K (1867) Capital: Volume One. London: Electric Book Company. Available at: https:// www.marxists.org/archive/marx/works/1867-c1/ch07.htm

Marx K (1894) Capital. Volume Three. London: Electric Book Company. Available at: http:// www.marxists.org/archive/marx/works/download/Marx_Capital_Vol_3.pdf

Marx K and Engels F (1965) The German Ideology. London: Lawrence and Wishart.

Mason J (2006) The animal question. In: Best S and Nocella AJ (eds) Igniting a Revolution. Voices in Defense of the Earth. Oakland: AK Press, pp.178-185.

Merchant C (1995) Earthcare Women and the Environment. New York: Routledge.

Merchant C (2005) Radical Ecology. The Search for a Livable World. New York: Routledge.

Millennium Ecosystem Assessment (2005) Ecosystems and Human Well-being: Synthesis. Available at: http://www.maweb.org/documents/document.356.aspx.pdf

Miller R (1991) Social and political theory: Class, state, revolution. In: Carver T (ed.) The Cambridge Companion to Marx. Cambridge: Cambridge University Press, pp.55-106.

Naess A (1983) The Shallow and the deep, long-range ecology movement. A summary. Inquiry 16: 95-100.

Parsons H (1977) Marx and Engels on Ecology. Connecticut: Greenwood Press Inc.

Pepper D (1993) Eco-socialism: From Deep Ecology to Social Justice. London: Routledge.

Peters M and Hung R (2009) Solar ethics: A new paradigm for envrionmental ethics and education? Policy Futures in Education 7(3): 321-329.

Plumwood V (2002) Environmental Culture The Ecological Crisis of Reason. New York: Routledge.

Redford K and Adams W (2009) Editorial: Payment for ecosystem services and the challenge of saving nature. Conservation Biology 23(4): 785-787.

Rolston HI (1999) A managed Earth and the end of nature? Research in Philosophy and Technology $143-164$.

Rousseau JJ (1979) Emile or On Education. New York: Basic Books, Inc.,Publishers.

Sahakian M and Sahakian W (1974) Rousseau as Educator. New York: Twayne Publishers.

Schmidt A (1971) The Concept of Nature in Marx. London: New Left Books.

Selby D (2002) The signature of the whole radical interconnectedness and its implications for global and environmental education. In: Morrell SEA and O'Connor M (eds) Expanding the Boundaries of Transformative Learning. USA: Palgrave, pp.68-81.

Shiva V (2005) Earth Democracy: Justice, Sustainability and Peace. London: Zed Books.

Smith N (1984) Uneven Development: Nature, Capital and the Production of Space. Oxford: Basil Blackwell.

Suchet S (2002) Totally Wild'? Colonising discourses, indigenous knowledges and managing wildlife. Australian Geographer 33(2): 141-157.

Thompson J (1983) Preservation of wilderness and the good life. In: Elliot R and Gare A (eds) Environmental Philosophy. Queensland: University of Queensland Press, pp.85-105. 
Tuhiwai Smith L (1999) Decolonizing methodologies. Research and indigenous peoples. Dunedin: University of Otago Press.

Viroli M (1988) Jean-Jacques Rousseau and the 'Well-Ordered Society'. Cambridge, UK: Cambridge Universtiy Press.

Whiteside K (2002) Divided Natures. Cambridge, Massachusetts: Massachusetts Institute of Technology.

Worster D (1993) The Wealth of Nature: Environmental History and the Ecological Imagination. Oxford: Oxford University Press.

Zhang W (2006). The concept of nature and historicism in Marx. Frontiers of Philosophy in China 1(4): 630-642. Available at: http://www.jstor.org.ezproxy.waikato.ac.nz/stable/pdfplus/30209879.pdf? acceptTC $=$ true.

Zimmerman ME (1994) Contesting Earth's Future: Radical Ecology and Postmodernity. Berkeley: University of California Press. 